\title{
Biomass-based carbon capture and utilization in kraft pulp mills
}

\author{
Katja Kuparinen $^{1} \cdot$ Esa Vakkilainen ${ }^{1} \cdot$ Tero Tynjälä $^{1}$
}

Received: 24 July 2018 / Accepted: 13 December 2018 / Published online: 4 January 2019

(C) The Author(s) 2019

\begin{abstract}
Corporate image, European Emission Trading System and Environmental Regulations, encourage pulp industry to reduce carbon dioxide $\left(\mathrm{CO}_{2}\right)$ emissions. Kraft pulp mills produce $\mathrm{CO}_{2}$ mainly in combustion processes. The largest sources are the recovery boiler, the biomass boiler, and the lime kiln. Due to utilizing mostly biomass-based fuels, the $\mathrm{CO}_{2}$ is largely biogenic. Capture and storage of $\mathrm{CO}_{2}$ (CCS) could offer pulp and paper industry the possibility to act as site for negative $\mathrm{CO}_{2}$ emissions. In addition, captured biogenic $\mathrm{CO}_{2}$ can be used as a raw material for bioproducts. Possibilities for $\mathrm{CO}_{2}$ utilization include tall oil manufacturing, lignin extraction, and production of precipitated calcium carbonate (PCC), depending on local conditions and mill-specific details. In this study, total biomass-based $\mathrm{CO}_{2}$ capture and storage potential (BECCS) and potential to implement capture and utilization of biomass-based $\mathrm{CO}_{2}$ (BECCU) in kraft pulp mills were estimated by analyzing the impacts of the processes on the operation of two modern reference mills, a Nordic softwood kraft pulp mill with integrated paper production and a Southern eucalyptus kraft pulp mill. $\mathrm{CO}_{2}$ capture is energy-intensive, and thus the effects on the energy balances of the mills were estimated. When papermaking is integrated in the mill operations, energy adequacy can be a limiting factor for carbon capture implementation. Global carbon capture potential was estimated based on pulp production data. Kraft pulp mills have notable $\mathrm{CO}_{2}$ capture potential, while the on-site utilization potential using currently available technologies is lower. The future of these processes depends on technology development, desire to reuse $\mathrm{CO}_{2}$, and prospective changes in legislation.
\end{abstract}

Keywords Bioenergy with carbon capture and storage BECCS · Bioenergy with carbon capture and utilization BECCU $\cdot \mathrm{Kraft}$ pulp mill $\cdot$ Climate change mitigation $\cdot \mathrm{Negative} \mathrm{CO}_{2}$

Katja Kuparinen

katja.kuparinen@lut.fi

1 Lappeenranta University of Technology, Skinnarilankatu 34, Lappeenranta, Finland 


\section{Introduction}

Pulp and paper production is one of the largest industrial energy users (IEA 2014). The raw material used in chemical pulping is mainly woody biomass. Over $80 \%$ of the carbon dioxide $\left(\mathrm{CO}_{2}\right)$ emissions are from burning of residual biomass. Of the global capacity, a significant portion is at forest industry sites (Vakkilainen et al. 2013). Comparison of global capacities of plants converting biomass for energy purposes shows that recovery boiler capacity is much larger than other biomass boiler capacities (Fig. 1).

Sustainability, emission trading and control, environmental regulations, corporate image, selfsufficiency of fuel supply, and the price of fossil fuels are among the many factors driving companies to reduce usage of fossil fuels. In the chemical pulp industry, a large share of energy use is already biomass-based, and in normal operations, modern kraft pulp mills are usually self-sufficient in energy, with the exception of lime kiln operations. Fossil fuels are primarily used to reduce lime mud to burnt lime. They are also used during upsets, start-up and shut-down, as well as sometimes for safety reasons, e.g., to secure non-condensable gas destruction (Vakkilainen and Kivistö 2008; Vakkilainen and Kivistö 2014). The lime kiln is typically the only unit operation utilizing fossil fuels during normal operations, and, consequently, the main source of fossil fuel-based emissions. When the woody raw material is from a sustainable origin, the mill operations can be considered carbonneutral except for fossil fuel use. Substituting fossil fuels used in the lime kiln with renewable fuels produced at the mill, especially if existing side streams are used, would make normal kraft pulp mill operations nearly fossil fuel-free. Feasible options to integrate renewable lime kiln fuel production into the kraft pulp production process exist (Kuparinen and Vakkilainen 2017).

This study provides an assessment of the global potential of pulp and paper industry to act as site for negative $\mathrm{CO}_{2}$ emissions through biomass-based $\mathrm{CO}_{2}$ capture and storage (BECCS) and what could be the share of internally utilized $\mathrm{CO}_{2}$ (biomass-based $\mathrm{CO}_{2}$ capture and utilization, BECCU). To clarify the potential to capture $\mathrm{CO}_{2}$, an analysis of modern Nordic

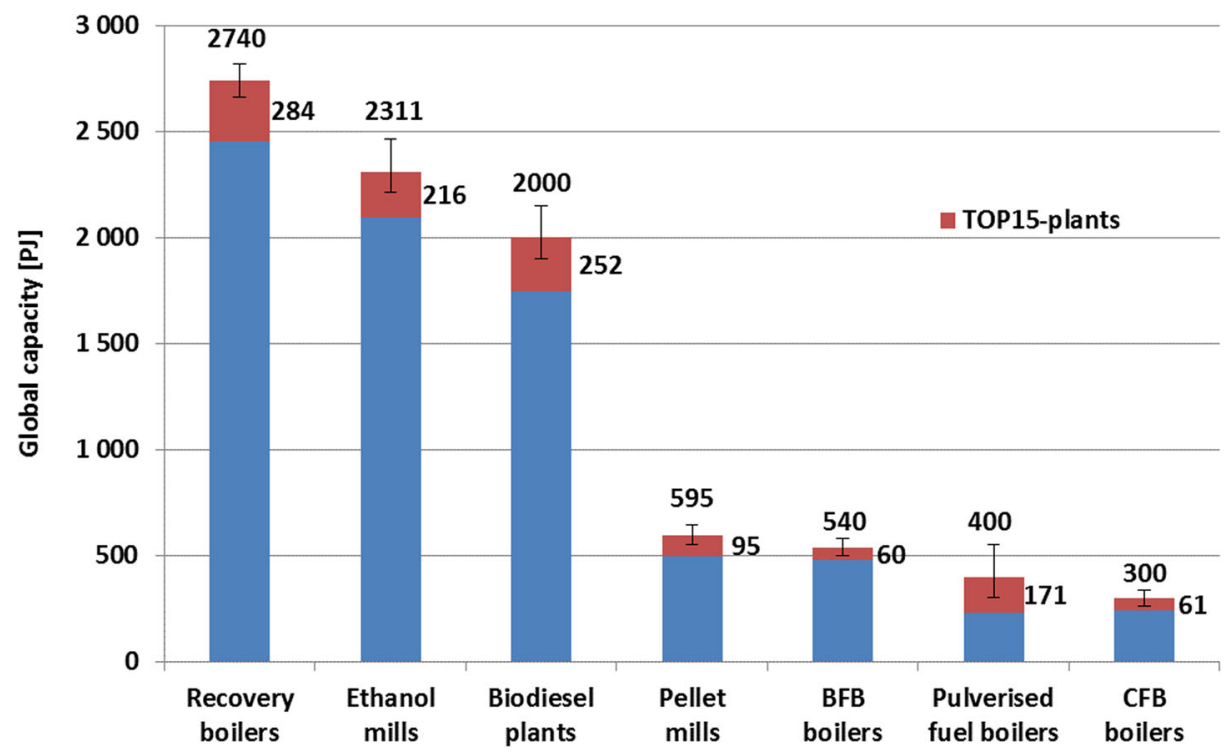

Fig. 1 Comparison of the global capacities (petajoules, PJ) of various types of biomass plants (Vakkilainen et al. 2013). BFB and CFB refer to bubbling fluidized bed and circulating fluidized bed, respectively 
Softwood Kraft Pulp Mill (Kuparinen et al. 2017) and Southern Eucalyptus Kraft Pulp Mill potential with alternative sources captured and the effect to their energy production is shown and discussed. The possibility to utilize captured $\mathrm{CO}_{2}$ as raw material for further bioproducts is explored.

\section{$2 \mathrm{CO}_{2}$ sources in kraft pulp mills}

The operation of a modern Nordic Softwood Kraft Pulp Mill and a Southern Eucalyptus Kraft Pulp Mill is analyzed, to clarify the potential to capture $\mathrm{CO}_{2}$ and the effect to their energy balances is shown and discussed. The magnitude of the recovery process is often not fully appreciated. The global sulfate pulp production was 137 million tons (t) in 2016 (FAO 2017). Consequently, more than 1300 million tons of weak black liquor was processed in recovery boilers globally and 206 million tons of black liquor dry solids was combusted (Tran and Vakkilainen 2007). The global energy generation in recovery boilers was thus approximately 1.8 exajoules (EJ). Based on statistics (IEA 2018), this makes black liquor the fifth most important fuel in the world after coal, oil, natural gas, and gasoline. In the industrial sector, recovery boilers were responsible for about a quarter of the global biomass-based energy generation in 2011 (Vakkilainen et al. 2013).

Carbon dioxide capture (CC) from lime kiln flue gasses and subsequent use as calcium carbonate paper filler is a well-known and widely applied technology (Hirsch et al. 2013). It is technically possible to retrofit post-combustion CC to an existing pulp or pulp and board mill recovery boiler or biomass boiler (IEAGHG 2016). Carbon dioxide capture processes use heat and power, which affects the energy balance of the mill. The adequacy of steam and electricity needs to be estimated based on mill-specific details and the requirements of the chosen $\mathrm{CC}$ process. Estimation on the effects of $\mathrm{CC}$ process implementation can be made by analyzing example mill processes. For instance, when aminebased post-combustion $\mathrm{CO}_{2}$ capture process is used in stand-alone mills, added steam use can be covered without need for an additional boiler (Onarheim et al. 2017).

\subsection{Sources of $\mathrm{CO}_{2}$}

$\mathrm{CO}_{2}$ is formed in kraft pulp mills primarily during combustion, when carbon (C) in the fuel oxidizes. The primary reaction is

$$
\mathrm{C}+\mathrm{O}_{2} \rightarrow \mathrm{CO}_{2}
$$

The main $\mathrm{CO}_{2}$ sources are the recovery boiler, the biomass boiler, and the lime kiln. Noncondensable gas (NCG) destruction with several vents is also a $\mathrm{CO}_{2}$ source, but a negligible one. Of these, typically, the lime kiln is the only fossil $\mathrm{CO}_{2}$ source. A simplified process diagram of a kraft pulp mill showing the main $\mathrm{CO}_{2}$ sources is depicted in (Fig. 2).

\subsection{Biomass boiler}

Biomass residue is generated in the wood handling processes of the pulp mill, and, in addition to bark, the biomass residues contain other particles such as fines and wood lost during mill debarking. Almost all pulp mills burn this residue at site in the biomass boiler. 


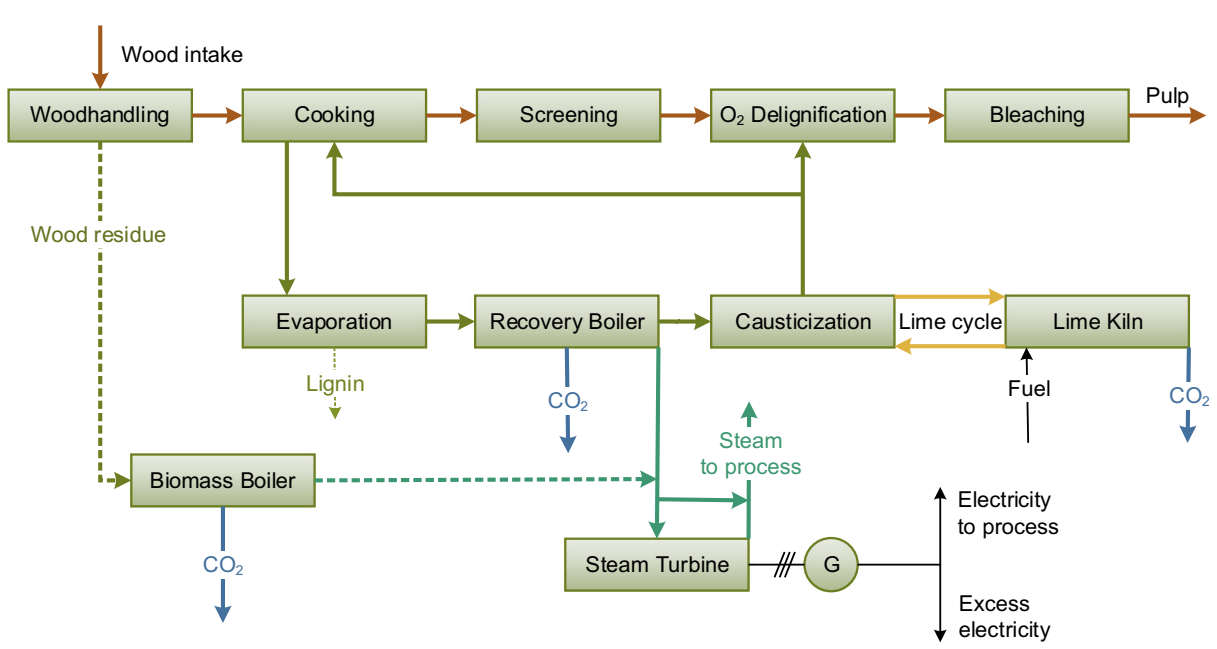

Fig. 2 Kraft pulp mill operations and alternative $\mathrm{CO}_{2}$-removal streams studied

Biomass boiler uses fossil fuels during startup and shutdown. In many mills, additional auxiliary steam is generated with fossil fuels especially if the mill is an integrated mill. Integrated mill combines the pulp mill and the paper machine. For pulp mill, the fossil fuel usage produces at least 20 kilograms $(\mathrm{kg}) \mathrm{CO}_{2}$ per air-dry pulp ton (ADt), but can be significantly larger.

\subsection{Recovery boiler}

Weak black liquor from brown stock washers after pulping is concentrated in multi-effect evaporator. Most of the water is removed, and concentrated black liquor, at 10-35\% water content, is burned in a recovery boiler. The role of the recovery boiler is to burn organic residue from pulping and recover used sodium-based pulping chemicals in the black liquor. As concentrated black liquor is sprayed into the lower part of the recovery boiler, the parts of wood, not used for pulp, are burned. In the lower part of the furnace, an oxygen deficient environment is maintained so that sodium sulfide $\left(\mathrm{Na}_{2} \mathrm{~S}\right)$ is preferably formed. The extent of sulfide formation over sulfate is measured by the reduction efficiency, typically over $90 \%$. The rest of the sodium reacts to carbonate. The inorganic sodium and sulfur are recovered as a molten smelt, which consists mostly of $\mathrm{Na}_{2} \mathrm{~S}$ and sodium carbonate $\left(\mathrm{Na}_{2} \mathrm{CO}_{3}\right)$. The molten smelt enters a dissolving tank where it is dissolved in almost water-like weak white liquor to form green liquor. Carbon dioxide in the carbonate is thus from biogenic source (Kuparinen and Vakkilainen 2017). Biogenic $\mathrm{CO}_{2}$ from the recovery boiler exits from the stack of the recovery boiler with the flue gas. Typically fossil fuels are used during startup and shutdown. Occasionally due sudden and large process upsets or equipment failure fossil fuels, mostly oil and natural gas are burned. Fossil fuel usage produces $10-20 \mathrm{~kg} \mathrm{CO} / \mathrm{ADt}$. Biogenic $\mathrm{CO}_{2}$ produced is $1600-2400 \mathrm{~kg} \mathrm{CO}_{2} / \mathrm{ADt}$.

\subsection{Lime kiln}

The green liquor from the recovery boiler is sent to the causticizing plant, where it reacts with lime $(\mathrm{CaO})$ to convert the $\mathrm{Na}_{2} \mathrm{CO}_{3}$ to sodium hydroxide $(\mathrm{NaOH})$ following the reactions 


$$
\begin{aligned}
& \mathrm{CaO}+\mathrm{H}_{2} \mathrm{O} \rightarrow \mathrm{Ca}(\mathrm{OH})_{2} \\
& \mathrm{Na}_{2} \mathrm{CO}_{3}+\mathrm{Ca}(\mathrm{OH})_{2} \rightarrow 2 \mathrm{NaOH}+\mathrm{CaCO}_{3} .
\end{aligned}
$$

Conversion is measured by causticizing efficiency, typically 80 to $85 \%$. Reaction product calcium carbonate $\left(\mathrm{CaCO}_{3}\right)$ is regenerated to $\mathrm{CaO}$ in the lime kiln with heat from burning typically fossil fuel according to the reduction reaction:

$$
\mathrm{CaCO}_{3}+(\text { heat }) \rightarrow \mathrm{CaO}+\mathrm{CO}_{2} .
$$

The reduction reaction produces biogenic $\mathrm{CO}_{2}$ that exits with the flue gasses from the stack of the lime kiln. Typically, fossil fuels are used to reach the required temperature, at least $850{ }^{\circ} \mathrm{C}$. Fossil fuel usage, mostly oil and natural gas, produces $100-250 \mathrm{~kg} \mathrm{CO}_{2} / \mathrm{ADt}$.

\subsection{Biogas production}

Liquid effluents from pulp mill are treated to high degree. Effluent flows contain small biomass particles (fiber sludge) that settle down. Separated material is called primary sludge. Very often the next step is biological treatment where remaining organics in the effluent are eaten by micro-organisms creating biosludge.

In some new mills, biosludge recovered is treated to biogas. Biogas production can be 10 15 kilowatt hours (kWh) per ADt (Metsä Group 2016). $\mathrm{CO}_{2}$ emissions from biogas production can be estimated growing, but of minor significance in relation to above-mentioned combustion processes.

\subsection{Studied mills}

The potential to capture $\mathrm{CO}_{2}$ within kraft pulp mill operations has been analyzed via case studies. The mass and energy balances of two reference mills were calculated and the most important $\mathrm{CO}_{2}$ sources were defined to estimate the $\mathrm{CC}$ potential and the effect of the implementation of the capture processes on the mill operations. The following reference mills were studied:

- $\quad$ Mill A

A modern softwood kraft pulp mill located in Northern Europe

Annual pulp production 1,400,000 ADt

Residue from woodhandling process combusted in a power boiler

Integrated paper mill producing coated and uncoated paper

- $\quad$ Mill B

A modern eucalyptus kraft pulp mill located in South America

Annual pulp production 1,500,000 ADt

The mills represent typical mills in their chosen location. Three hundred and fifty annual operating days was estimated for the both mills. The mill balances were calculated using an updated MillFlow program. The program includes detailed mass and energy balances and has been used to design pulp mills and to evaluate new process alternatives (Vakkilainen and 
Kivistö 2008; Hamaguchi et al. 2011). The Millflow balances include hundreds of calculations, which were introduced in more detail earlier (Hamaguchi et al. 2011). In the program, the pulping line is dimensioned based on the desired capacity of the mill. The wood demand is calculated based on the cooking yield and losses in the process stages, and the chemical demand is calculated from the digester balance. The program includes a black liquor calculation tool to define the inputs for the recovery boiler calculations, such as the dry solids flow, the composition, and the heating value of black liquor. The electricity generation is calculated from turbo generator balances after defining the steam flows from the recovery boiler and the biomass boiler. The electricity and heat usage in each department of the mill is used to define the steam balance. The lime kiln calculations require that inputs such as the type of make-up lime, the amount of residual lime, and the availability of burnt lime are defined. During this study, a carbon capture unit was added to calculate how carbon capture affects the balances of the reference mills.

Mill A is a large integrated pulp and paper mill located in Northern Europe. The recovery boiler and a separate biomass boiler produce steam for use in mill processes and for electricity generation in a steam turbine. The integrated paper mill is a notable steam and electricity consumer. Biomass boiler is fueled with woody residue from the wood handling process of the mill. The recovery boiler combusting black liquor and the biomass boiler produce biogenic $\mathrm{CO}_{2}$ due to biomass-based fuels. Natural gas is used as lime kiln fuel. A more detailed description of the Northern reference mill operations can be found in a previous work (Kuparinen et al. 2017).

Mill B is a South American stand-alone kraft pulp mill producing market pulp from eucalyptus (Eucalyptus globulus). Steam is generated in the recovery boiler that is able to cover the heat and electricity demand of the mill, and a separate biomass boiler is not used. Eucalyptus is typically debarked in the forest, and therefore the amount of on-site woody residue is relatively small compared with Northern mills. The lime kiln is fired with oil, which is typical when the mill is not located near the natural gas grid. Earlier studies introduced the operations of this reference mill in more detail (Kuparinen and Vakkilainen 2017; Hamaguchi et al. 2011).

Simplified block diagrams of Mill A and Mill B (Figs. 3 and 4) show the primary $\mathrm{CO}_{2}$ sources in the reference mills. The main process values of the reference mills are typical for new mills (Table 1). The biomass boiler in Mill A is assumed to combust all biomass residues generated, and the amount of $\mathrm{CO}_{2}$ is calculated accordingly. The figures represent a normal operation situation, and therefore, fossil fuels used during startups and shutdowns are not shown in the figures. The $\mathrm{CO}_{2}$ from fossil fuels used during startup and shutdown can be estimated at $10-20 \mathrm{~kg} \mathrm{CO} / \mathrm{ADt}$. The lime kiln produces both fossil, fuel-based $\mathrm{CO}_{2}$, and biogenic $\mathrm{CO}_{2}$ originating from the lime reburning reaction. In the reference mill cases, $64 \%$ of lime kiln $\mathrm{CO}_{2}$ is biogenic for Mill A, and $55 \%$ for Mill B.

\section{$3 \mathrm{CO}_{2}$ removal}

As described above, the main $\mathrm{CO}_{2}$ emission sources in a kraft pulp mill arise from the recovery boiler, the biomass boiler (when present), and the lime kiln, from which the recovery boiler is the largest point source. $\mathrm{CO}_{2}$ removal is energy intensive and removal cost depends on removal method and process integration possibilities. Considering only carbon flows across the plant borders presented (Figs. 3 and 4), a 


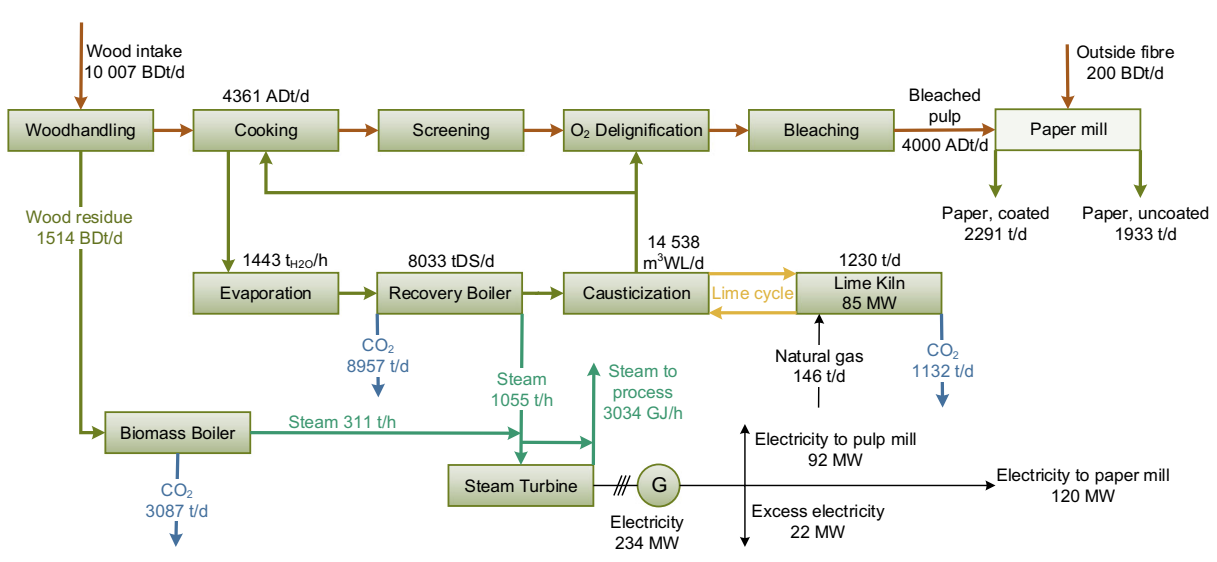

Fig. 3 Simplified block diagram of the operations of Mill A, a modern softwood kraft pulp mill located in Northern Europe. The values are given on hourly (h) or daily (d) basis. AD refers to air-dry, BD to bone-dry, DS to dry solids, and WL to white liquor

simplified carbon balance and net $\mathrm{CO}_{2}$ emissions from the process $\left(\mathrm{CO}_{2, \text { net }}\right)$ can be defined for the process as follows

$$
\mathrm{CO}_{2, \text { net }}=\left(\mathrm{C}_{\mathrm{f}}+\mathrm{C}_{\mathrm{CaCO} 3}\right) \frac{\mathrm{M}_{\mathrm{CO} 2}}{\mathrm{M}_{\mathrm{C}}}-\eta_{\mathrm{CCU}} \eta_{\mathrm{CC}} \mathrm{CO}_{2, \text { total }}
$$

where $\eta_{\mathrm{CC}}$ is the share of $\mathrm{CO}_{2}$ removed from the total $\mathrm{CO}_{2}$ emissions $\left(\mathrm{CO}_{2, \text { total }}\right)$ and depends on capture method and how it is applied. Most likely it is not feasible to apply $\mathrm{CO}_{2}$ removal for all possible $\mathrm{CO}_{2}$ streams, but rather to consider only the largest one(s). For example in Mill A and Mill B, the share of total emissions from the recovery boiler are $68 \%$ and $87 \%$, respectively. If the efficiency of $\mathrm{CO}_{2}$ capture process is $90 \%$, it follows that $\eta_{\mathrm{CC}, \mathrm{A}}=61 \%$ and $\eta_{\mathrm{CC}, \mathrm{B}}=78 \%$. Depending on $\mathrm{CO}_{2}$

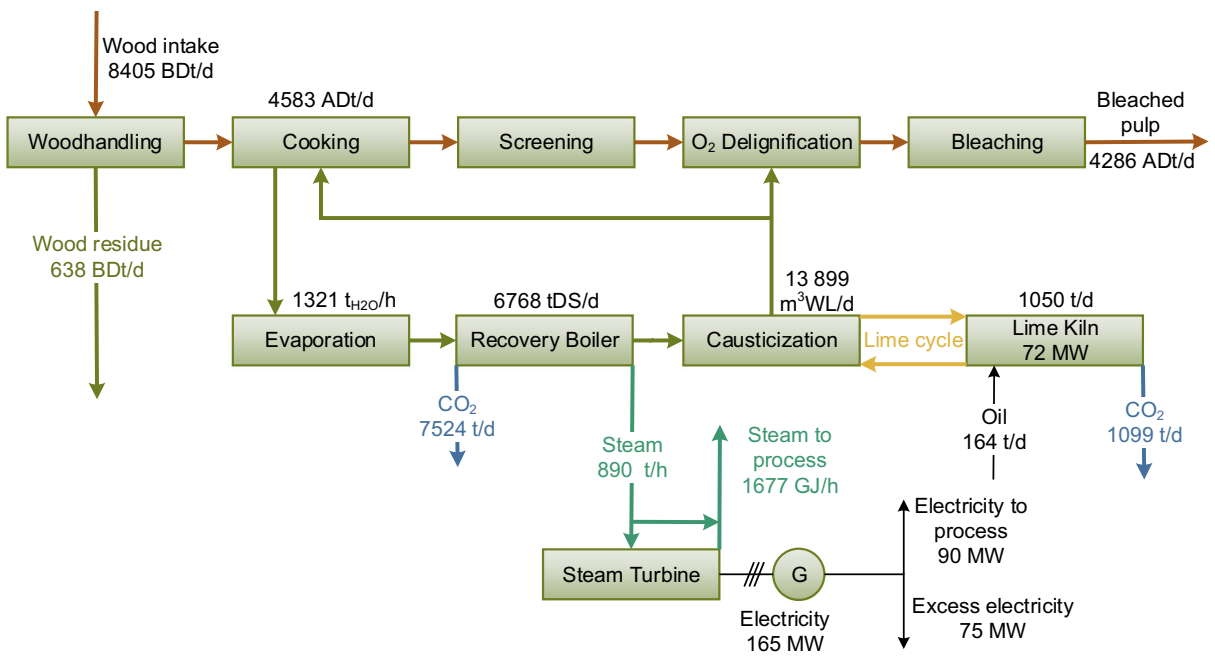

Fig. 4 Simplified block diagram of the operations of Mill B, a modern eucalyptus kraft pulp mill located in South America. The values are given on hourly (h) or daily (d) basis. AD refers to air-dry, BD to bone-dry, DS to dry solids, and WL to white liquor 
Table 1 The main process values and $\mathrm{CO}_{2}$ sources of the reference mills. The values are given on annual (a), daily (d), or hourly (h) basis. MW refers to megawatt

\begin{tabular}{|c|c|c|c|}
\hline & Unit & Mill A & Mill B \\
\hline \multicolumn{4}{|l|}{ Production } \\
\hline -Operating hours & $\mathrm{h} / \mathrm{a}$ & 8400 & 8400 \\
\hline -Pulp production & $\mathrm{ADt} / \mathrm{d}$ & 4000 & 4286 \\
\hline -Paper production & $t / d$ & 4224 & - \\
\hline \multicolumn{4}{|l|}{ Recovery boiler } \\
\hline -Black liquor flow, dry matter & $\mathrm{tDS} / \mathrm{d}$ & 8033 & 6768 \\
\hline -Net steam flow & $\mathrm{t} / \mathrm{h}$ & 1055 & 890 \\
\hline$-\mathrm{CO}_{2}$ production & $t / d$ & 8957 & 7524 \\
\hline \multicolumn{4}{|l|}{ Biomass boiler } \\
\hline -Biomass fuel use & $\mathrm{BDt} / \mathrm{d}$ & 1514 & - \\
\hline -Net steam flow & $\mathrm{t} / \mathrm{h}$ & 311 & - \\
\hline$-\mathrm{CO}_{2}$ production & $t / d$ & 3087 & - \\
\hline \multicolumn{4}{|l|}{ Lime kiln } \\
\hline Lime production & $t / d$ & 1230 & 1050 \\
\hline Makeup limestone & $t / d$ & 60 & 77 \\
\hline Fuel consumption & $t / d$ & 146 & 164 \\
\hline $\mathrm{CO}_{2}$ production & $t / d$ & 1132 & 1099 \\
\hline \multicolumn{4}{|l|}{ Energy } \\
\hline -Mill steam use & $\mathrm{t} / \mathrm{h}$ & 1109 & 660 \\
\hline -Power generation & MW & 234 & 165 \\
\hline -Mill power consumption & MW & 212 & 90 \\
\hline
\end{tabular}

source and emissions of electricity production, in $\mathrm{CO}_{2}$ to fuel conversion emissions in $\mathrm{CCU}$ route may exceed the fossil emissions (Abanades et al. 2017). Net negative $\mathrm{CO}_{2}$ emissions can be reached only, if at least part of the captured $\mathrm{CO}_{2}$ will be permanently removed from the atmosphere. $\eta_{\mathrm{CCU}}$ gives the $\mathrm{CO}_{2}$ emission effect of selected $\mathrm{CO}_{2}$ utilization and storage route, where $100 \%$ means that all captured $\mathrm{CO}_{2}$ is permanently removed from the atmosphere, without additional emissions from the storage/utilization process. $\mathrm{C}_{\mathrm{f}}$ and $\mathrm{C}_{\mathrm{CaCO}}$ are carbon flows into the plant in fossil fuel and limestone makeup streams. $M_{\mathrm{CO} 2}$ and $M_{C}$ refer to molar masses of $\mathrm{CO}_{2}$ and C. For two studied Mill types where the capture process is applied only on recovery boiler, the net specific $\mathrm{CO}_{2}$ emission curves show substantial recovery potential for a single mill (Fig. 5). Specific emissions have large variation, depending on capture process efficiency and the $\mathrm{CO}_{2}$ emissions of the utilization route. When global potential for negative emissions is estimated roughly in Section 5, average specific emissions of $-1 \mathrm{t} \mathrm{CO}_{2} / \mathrm{ADt}$ is used for a general kraft pulp mill with $\mathrm{CO}_{2}$ capture and utilization.

\section{1 $\mathrm{CO}_{2}$ removal methods}

Different technologies based on pre-, post- or oxy-combustion processes can be utilized for $\mathrm{CO}_{2}$ capture from pulp mills. Leeson et al. (2017) recently presented techno-economic analysis and review of different $\mathrm{CO}_{2}$ removal methods applied to different industrial $\mathrm{CO}_{2}$ sources. Also, pulp and paper industries were touched and it was determined that not many detailed studies have been applied to pulp mills. It was also noticed that there is no single winning technology in terms of costs and that benchmarking is difficult due to inconsistent literature. 


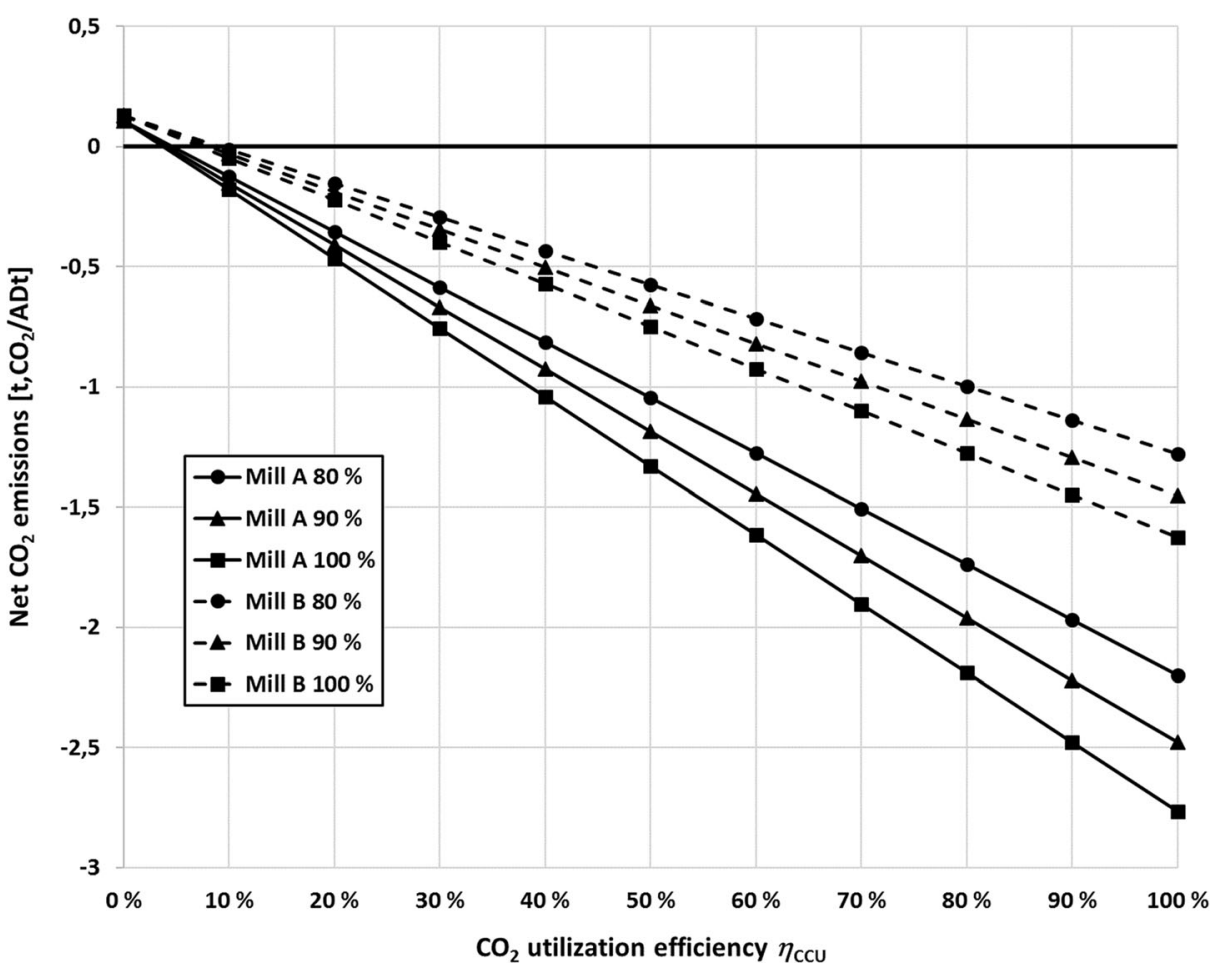

Fig. 5 Net $\mathrm{CO}_{2}$ emissions per produced dry ton of pulp from Mill A and Mill B for different capture efficiencies $(80 \%, 90 \%, 100 \%)$, when $\mathrm{CO}_{2}$ capture is applied only on recovery boiler flue gasses. In this work, average specific emissions of $-1 \mathrm{t}, \mathrm{CO}_{2} / \mathrm{ADt}$ is used for a general kraft pulp mill with $\mathrm{CO}_{2}$ capture and utilization

Amine-based post combustion $\mathrm{CO}_{2}$ capture systems are a proven technology that is commercially available. $\mathrm{CO}_{2}$ capture efficiency of monoethanolamine (MEA) process is usually between 80 and $90 \%$ and as a post combustion method, it can be applied easily to existing plants. Aqueous solution (30 percentage by weight) of MEA can be considered as a reference solvent in post combustion capture process. $\mathrm{CO}_{2}$ is absorbed at temperature 45$50{ }^{\circ} \mathrm{C}$ and flue gasses need to be cooled before amine absorption. Desorption occurs at 100 $120{ }^{\circ} \mathrm{C}$ and approximately 3.7 megajoules $(\mathrm{MJ})$ per $\mathrm{kg}, \mathrm{CO}_{2}$ heat is needed for sorbent regeneration. In addition, some electricity is needed for the process, which increases own electricity use of the mill (Onarheim et al. 2015).

In recent study, Karjunen et al. (2017) studied the application of $\mathrm{CO}_{2}$ capture, transport, and intermediate storage logistics for Finnish energy system based on renewable energy sources. The cost of biogenic $\mathrm{CO}_{2}$ for utilization varied between 40 and $44 € / t, \mathrm{CO}_{2}$ depending on applied future scenario. Costs were lowest for industrial scenario, where the largest amount of $\mathrm{CO}_{2}$ was captured from large industrial (mainly pulp and paper) point sources. In the calculations, conventional MEA capture process was taken as reference capture method. Application of more advanced capture methods could lead to lower capture costs.

Oxycombustion processes (see e.g., Stanger et al. 2015) applied to recovery boiler, bark boiler, or lime kiln are one option but require oxygen source and possibly modifications to the flue gas passages. In oxycombustion processes, reaction zones and gas atmosphere in the furnace will change, which may have implications on heat transfer and reactions that should be 
taken into account. Main additional cost is production of oxygen, which in case of kraft pulp mills can be quite affordable due to often preexisting equipment on site. In addition, precombustion processes based on black liquor gasification have been suggested for $\mathrm{CO}_{2}$ capture but these technologies have not yet been demonstrated successfully commercially (Onarheim et al. 2015).

Advanced hot solid looping technologies such as post-combustion calcium looping (CaL) (Martínez et al. 2016) offer also interesting possibilities for $\mathrm{CO}_{2}$ capture. In $\mathrm{CaL}$, process calcium oxide is used for $\mathrm{CO}_{2}$ capture. In the case of kraft pulp mill, it has been proposed that lime mud from the lime kiln could be used as a sorbent for $\mathrm{CO}_{2}$ capture in pulp mills (Sun et al. 2013; Tynjälä et al. 2014). Even if lime mud as is would not be feasible choice for $\mathrm{CO}_{2}$ capture, there are other integration possibilities with $\mathrm{CaL}$ process and lime kiln, and also existing infrastructure for limestone acquisition and handling in a pulp mill, which could lead to further integration benefits. For CaL process integrated to lime kiln of a cement plant, Romano et al. (2013) estimated that the minimum cost of $\mathrm{CO}_{2}$ avoided could be as low as 27 $€ / \mathrm{t}, \mathrm{CO}_{2}$.

\subsection{Effect of capture to energy use}

$\mathrm{CO}_{2}$ capture processes are energy-intensive, and therefore, the effect of the process on the reference mill energy balances was estimated. MEA-based post-combustion process and capture from recovery boiler flue gas flow were chosen for the calculations. The consumption of low-pressure steam, cooling water, and electricity were estimated based on a previous study (Onarheim et al. 2015). The effect of capture process to energy use in reference mills is presented in Table 2.

Due to integrated paper production, Mill A is a large energy consumer compared with a stand-alone pulp mill. Additional steam used in $\mathrm{CO}_{2}$ capture reduces electricity generation. If the energy use is limited to mill's own production, availability of electricity sets the maximum limits for the capture process. Without additional electricity, $21 \%$ of $\mathrm{CO}_{2}$ in the recovery boiler flue gas flow can be captured without additional energy generation. This equals to $14 \%$ of the total $\mathrm{CO}_{2}$ of the mill. If carbon capture is used together with another process influencing the energy balance, such as lignin extraction, energy adequacy may become an issue.

Mill B is a stand-alone pulp mill where electricity is produced substantially in excess of own use. In this case, the limiting factor is the adequacy of steam, when steam production is limited to the recovery boiler and no additional boiler exists. The capture process consumes low-pressure steam. Based on the steam balance calculations, the maximum capture rate from recovery boiler flue gas flow is $32 \%$, which equals to a capture rate of $28 \%$ of the total $\mathrm{CO}_{2}$ emissions of the mill. The mill steam consumption increases then by $22 \%$. Electricity consumption increases by $12 \%$ and production decreases by $10 \%$.

Table 2 The effect of carbon capture process in the energy balances of reference mills, when MEA based postcombustion process is used to capture $\mathrm{CO}_{2}$ from recovery boiler flue gas

\begin{tabular}{llllll}
\hline & Unit & Mill A Base & Mill $\mathrm{A} \mathrm{CO}_{2}$ capture & Mill B Base & Mill B CO $_{2}$ capture \\
\hline $\mathrm{CO}_{2}$ capture & $\mathrm{t} / \mathrm{d}$ & - & 1881 & - & 2378 \\
Mill steam use & $\mathrm{t} / \mathrm{h}$ & 1109 & 1225 & 860 & 807 \\
Power generation & $\mathrm{MW}$ & 234 & 221 & 195 & 149 \\
Power consumption & $\mathrm{MW}$ & 212 & 221 & 90 & 101 \\
\hline
\end{tabular}




\section{$4 \mathrm{CO}_{2}$ utilization in kraft pulp mills}

The possibility to utilize captured $\mathrm{CO}_{2}$ as raw material for further bioproducts is explored. The possibilities depend on mill-specific details, such as the chosen processes and the type of wood raw material. The studied alternatives for on-site utilization of $\mathrm{CO}_{2}$ are typically occurring large streams; tall oil manufacturing, lignin extraction, and production of precipitated calcium carbonate (PCC). Tall oil manufacturing can be considered as an option in softwood mills, but in hardwood and eucalyptus mills tall oil recovery is rarely done due to low levels of extractives (Shackford 2003). Lignin extraction can be integrated in both hardwood and softwood mills. There are several uses for the separated lignin; formaldehyde resins, carbon fibers, moisture barriers in packaging materials and upgraded fuel (Tomani 2013). In the case of an integrated pulp and paper mill, $\mathrm{CO}_{2}$ can be used in PCC production (Teir et al. 2005).

\subsection{Tall oil manufacture}

After pulping, weak black liquor contains fatty and rosin acid extractives as foamy material called soap. Especially, coniferous trees have high extractive content. Soap in black liquor is separated and skimmed from feed and intermediate liquor tanks in the evaporation plant. Raw soap is converted to crude tall oil (CTO) by acidulation in the tall oil plant. Tall oil production varies and can be estimated as $45 \mathrm{~kg} / \mathrm{ADt}$ for Nordic pine (Pinus sylvestris), $25 \mathrm{~kg} / \mathrm{ADt}$ for Nordic spruce (Picea abies) and less than $20 \mathrm{~kg} / \mathrm{ADt}$ for Nordic birch (Betula pendula, Betula pubescens) (Gullichsen and Lindeberg 2000). Acidulation is typically done using sulfuric acid. Acid use is $200-300 \mathrm{~kg}$ of sulfuric acid per ton of crude tall oil. Sometimes rest acid from chlorine dioxide $\left(\mathrm{ClO}_{2}\right)$ plant can be partially used. Part of the acid can be replaced by the use of $\mathrm{CO}_{2}$. Because $\mathrm{CO}_{2}$ is weaker acid only about $50 \%$ of acid use can be replaced. $\mathrm{CO}_{2}$ use corresponds to 4-6 kg/ADt.

Due to the environmental footprint associated with the use of fossil fuels, it is of great economic importance to produce fuels from other sources. Tall oil can be converted to a renewable fuel at a low cost and offers competitive advantage against alternative biomaterials, such as vegetable oil (Aro and Fatehi 2017).

\subsection{PCC production}

In integrated mills, part of the coating materials for paper production can be produced by blowing, e.g., lime kiln flue gas through slurry of calcium hydroxide solution. Produced calcium carbonate is then used to whiten and smoothen the paper surface (Nanri et al. 2008).

Typically, lime kiln flue gasses are bubbled through green liquor. The amount of calcium carbonate produced is typically fixed to correspond the local demand. A possible production level could be $33 \mathrm{kgCaCO}_{3} / \mathrm{ADt}$ corresponding to $\mathrm{CO}_{2}$ use of $20 \mathrm{~kg} / \mathrm{ADt}$.

\subsection{Lignin separation}

Major wood components are cellulose 40-50\%, hemicellulose 23-32\%, and lignin 15-30\%. About half of the original wood, most of the cellulose and some hemicelluloses is converted to kraft pulp and the rest of the organics in wood are led through evaporation plant to energy production in recovery boiler. 
The separation of lignin from residual black liquor is an option that is considered by the pulp mills for several reasons. Firstly, the heat transfer capacity of the recovery boiler is often a bottleneck that limits pulp production. Removing part of the lignin from the black liquor decreases the heat load on the recovery boiler and more pulp can be produced. The separated lignin could be sold or used to replace, e.g., fuel oil or natural gas in the lime kilns or be combusted in a power boiler if the energy is required. Secondly, the modern pulp mills have energy surplus and this energy surplus can be exported to other users in the form of biofuel. Thirdly, separated lignin can be used as a raw material in chemicals (Hamaguchi et al. 2013).

Typically, lignin is separated by acidifying part of the black liquor. Sulfuric acid is used for acidification. The use is $50-100 \mathrm{~kg}$ per ton of separated lignin. In many commercial processes, part of the acidification is done by $\mathrm{CO}_{2}$. The $\mathrm{CO}_{2}$ use is then $150-250 \mathrm{~kg}$ per ton of separated lignin. If lignin separation degree is $20 \%$ and the wood pulped is pine, then the $\mathrm{CO}_{2}$ use is about $35 \mathrm{~kg} / \mathrm{ADt}$.

\section{4 $\mathrm{CO}_{2}$ utilization processes in the reference mills}

Compared with carbon capture potential, the utilization possibilities are currently small. Considering the $\mathrm{CO}_{2}$ requirement of the above-mentioned utilization processes, required carbon capture rates at the reference mills vary from 0.2 to $21.6 \%$ depending on the chosen process/processes and $\mathrm{CO}_{2}$ source (Table 3). Tall oil production was considered only for Mill A, because in eucalyptus mills tall oil recovery is rarely done due to pulp properties. PCC production was also considered for Mill A due to integrated paper production. Lignin separation rate was chosen at $20 \%$ for both mills.

The main process flows of Mills A and B with integrated CCU processes are presented in Figs. 6 and 7. For Mill A, all the three possible options are shown, although implementation of each of them would require generation or purchase of additional electricity. This results from increased electricity consumption due to new processes and decrease in steam generation in the recovery boiler due to lignin extraction. Capture from recovery boiler flue gas was chosen except for PCC production, where lime kiln flue gas is used.

\section{Global potential}

This study provides an assessment of the global potential of pulp and paper industry to act as site for negative $\mathrm{CO}_{2}$ emissions. Estimates are given based on recent production data (FAO

Table 3 Required $\mathrm{CO}_{2}$ capture rates to cover for selected $\mathrm{CO}_{2}$ utilization processes in reference mills $\mathrm{A}$ and $\mathrm{B}$. Capture rates calculated for the flue gasses from the recovery boiler (RB), biomass boiler (BB), and lime kiln (LK)

$\mathrm{CO}_{2}$ capture rate

\begin{tabular}{lll}
\hline $\mathrm{RB}(\%)$ & $\mathrm{BB}$ & $\mathrm{LK}(\%)$
\end{tabular}

\begin{tabular}{llll}
\hline Mill A & & & \\
Tall oil production & $0.2-0.3$ & $0.5-0.8 \%$ & $1.4-2.1$ \\
PCC production & 0.9 & $2.6 \%$ & 7.1 \\
Lignin separation & 1.6 & $4.5 \%$ & 12.4 \\
Tall oil+PCC+lignin & 2.7 & $7.9 \%$ & 21.6 \\
Mill B & & & $7.0-11.7$ \\
Lignin separation & $1.1-1.8$ & - & \\
\hline
\end{tabular}




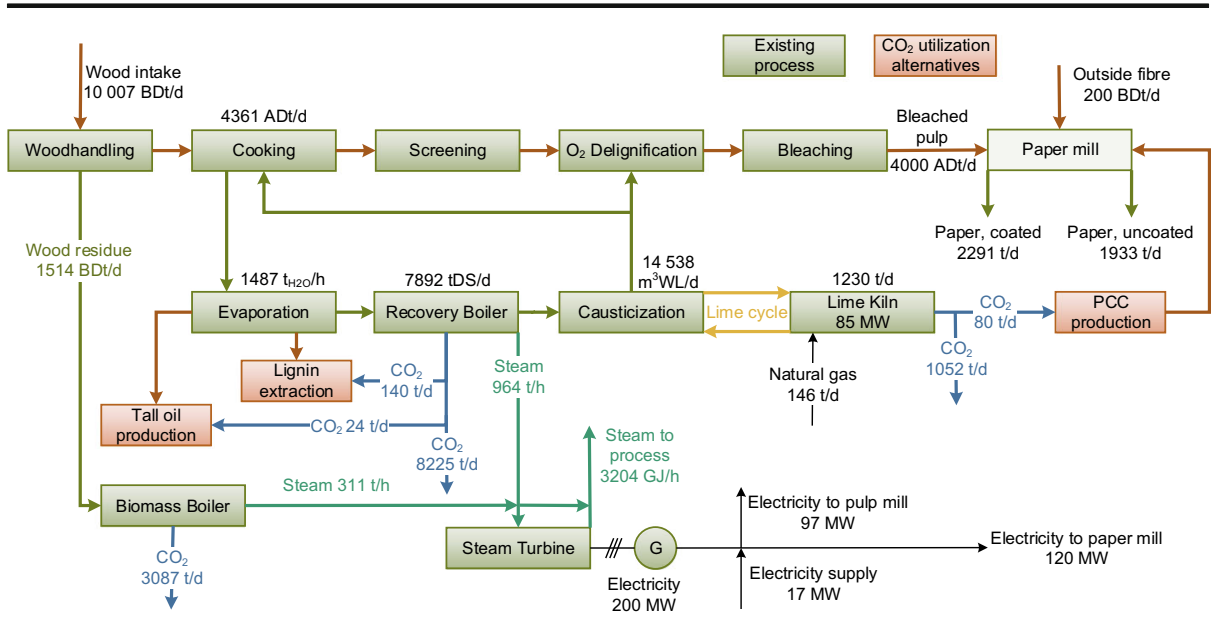

Fig. 6 The main process flows for Mill A when the studied CCU processes are implemented

2017). The development trend of the global chemical wood pulp production from the year 1961 to 2016 shows almost constant growth (Fig. 8).

The estimated $\mathrm{CO}_{2}$ production of the 15 largest unbleached and bleached sulfate pulp producer countries based on production in the year 2016 is more than 300 megatons (Mt) (Fig. 9). These countries produced $93 \%$ of the global sulfate pulp production and therefore, substantial CCU potential can be expected.

The global technical potential to capture $\mathrm{CO}_{2}$ from kraft pulp mill recovery boilers, lime kilns, and biomass boilers was estimated based on chemical pulp production data from the year 2016 (FAO 2017). The estimates were made for bleached and unbleached sulfate pulp, and were about 100 and $35 \mathrm{MtCO}_{2}$ /a respectively (Table 4). Technical potential to utilize $\mathrm{CO}_{2}$ in the mill processes using above-mentioned technologies was estimated about 12 and $4 \mathrm{MtCO}_{2} / \mathrm{a}$ respectively (Table 4).

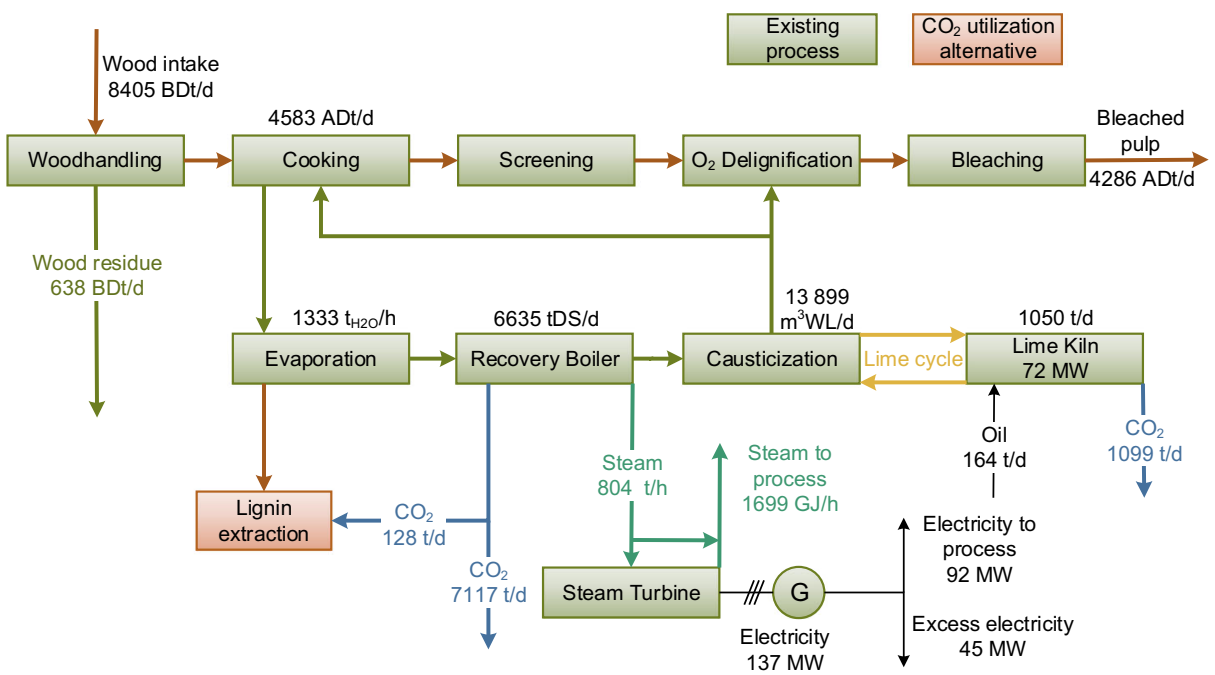

Fig. 7 The main process flows for Mill $\mathrm{B}$ when $\mathrm{CO}_{2}$ from the recovery boiler is utilized for lignin separation 


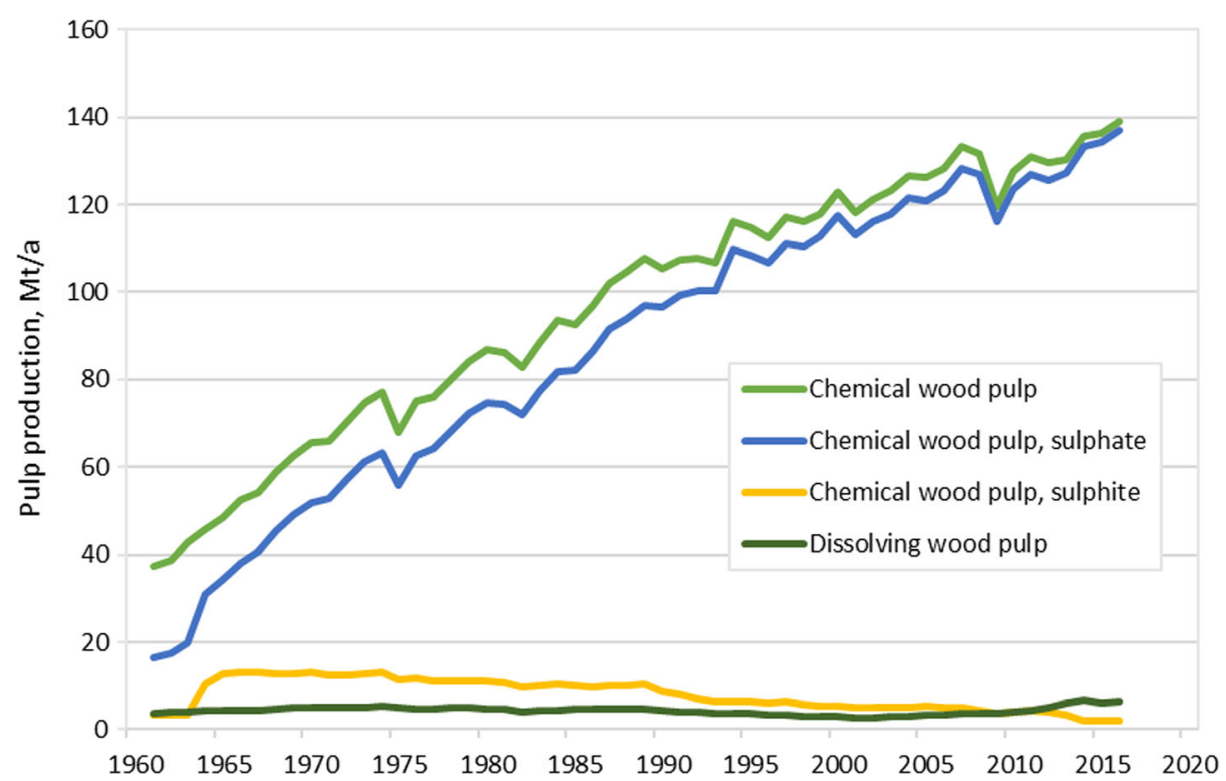

Fig. 8 World wood chemical pulp production, data from FAO 2017

Technical potential to capture $\mathrm{CO}_{2}$ from pulp mills is substantial. With rather conventional assumptions presented above, total amount of about $135 \mathrm{MtCO}_{2} /$ a could be removed from the atmosphere from existing pulp mills, without additional biomass harvesting at price levels well below $50 € / t, \mathrm{CO}_{2}$. Pulp mills alone are not answer to high negative emission targets but they can be one significant component in the palette. With currently available technologies, only a

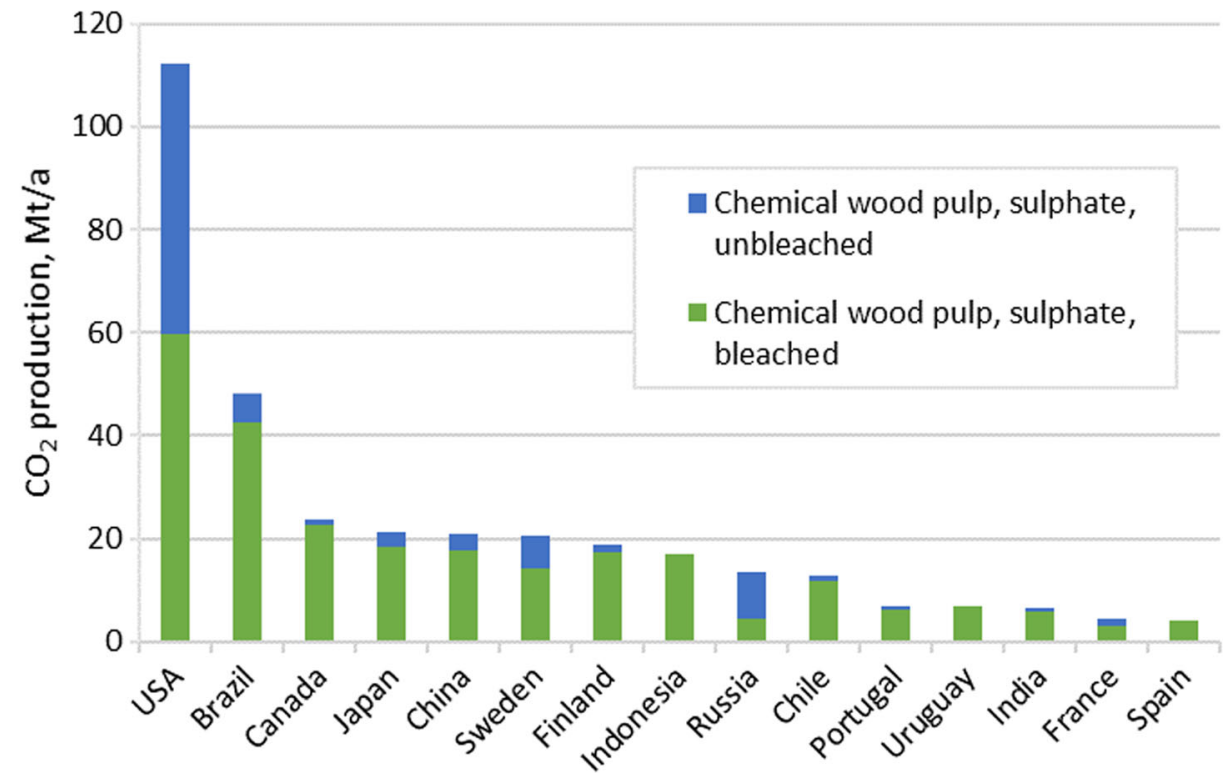

Fig. $9 \mathrm{CO}_{2}$ production, including both biogenic and fossil-based $\mathrm{CO}_{2}$, of the largest sulfate pulp producer countries in the year 2016. Estimation based on pulp production data (FAO 2017) 
Table 4 Global technical potential to capture $\mathrm{CO}_{2}$ from recovery boilers (RB), biomass boilers (BB), and lime kilns (LK) and on-site utilization potential, estimations based on sulfate pulp production data from the year 2016 (FAO 2017)

\begin{tabular}{|c|c|c|c|c|c|c|}
\hline & \multicolumn{3}{|c|}{$\mathrm{CO}_{2}$ capture potential } & \multicolumn{3}{|c|}{$\mathrm{CO}_{2}$ utilization potential } \\
\hline & \multicolumn{3}{|c|}{$1000 \mathrm{tCO}_{2} / \mathrm{a}$} & \multicolumn{3}{|c|}{$1000 \mathrm{tCO}_{2} / \mathrm{a}$} \\
\hline & $\mathrm{RB}$ & $\mathrm{BB}$ & LK & Tall oil & PCC & Lignin \\
\hline Bleached sulfate pulp & 76,264 & 14,731 & 10,297 & 1102 & 4409 & 7149 \\
\hline \multirow[t]{2}{*}{ Unbleached sulfate pulp } & 26,909 & 5198 & 3633 & 389 & 1556 & 2522 \\
\hline & \multicolumn{6}{|c|}{ Share of total $\mathrm{CO}_{2}$ from sulfate pulp production } \\
\hline Bleached sulfate pulp & $21 \%$ & $4 \%$ & $3 \%$ & $0.3 \%$ & $1.2 \%$ & $2.0 \%$ \\
\hline Unbleached sulfate pulp & $7 \%$ & $1 \%$ & $1 \%$ & $0.1 \%$ & $0.4 \%$ & $0.7 \%$ \\
\hline
\end{tabular}

Total capture potential $137 \mathrm{MtCO}_{2} / \mathrm{a}$

small part of produced $\mathrm{CO}_{2}$ can be utilized on-site. The potential for both capture and utilization can be estimated to increase along with technology development as well as the steady increase of pulp production capacity with new mills. Commercial potential of $\mathrm{CO}_{2}$ utilization routes was not estimated in this study.

In recent mitigation strategies for climate change, BECCS has been presented as one of the key technologies, as it offers a way to negative $\mathrm{CO}_{2}$ emissions (Fridahl and Lehtveer 2018; IPCC 2018). The global annual BECCS potential has been estimated at or below 5 gigatons (Gt) $\mathrm{CO}_{2}$ (de Coninck et al. 2018). Based on the estimation above, capture from chemical pulp industry can cover at least $3 \%$ of the global potential. Technology is not yet mature, but it is tested and used in small scale. The deployment of BECCS/CCU in the pulp industry does not affect the wood use of the mills, and therefore has no effect on forest or land use when applied to existing mills. Sociopolitical issues are the primary constraints on the way to BECCS and its large-scale use (Fridahl and Lehtveer 2018).

In addition to the investment and operational costs, the economic feasibility of BECCS/ $\mathrm{CCU}$ is greatly dependent on the avoided $\mathrm{CO}_{2}$ costs, primarily taxes and emissions credit collected on fossil-based emissions. It should be noted that as currently, $\mathrm{CO}_{2}$ in chemicals is counted at production source; therefore, use of biogenic $\mathrm{CO}_{2}$ replacing fossil $\mathrm{CO}_{2}$ would give the mill no credits. Therefore, apart from development of carbon utilization technologies, the future of BECCS/CCU depends on political decisions. Incentives for negative emissions would be a probable way to encourage producers to adopt these processes. Utilization of biogenic $\mathrm{CO}_{2}$ in the processes of an emission producer is a novel concept, and thus unknown as a legislative issue.

\section{Conclusions}

This study evaluated the possibilities of $\mathrm{CO}_{2}$ capture and on-site utilization in pulp mills. Bioenergy with carbon capture and storage or utilization has been recognized as one of the key technologies in recent strategies on climate change mitigation. In kraft pulp mills, three main $\mathrm{CO}_{2}$ sources can be identified as the recovery boiler, the lime kiln, and in most mills, the biomass boiler. Large part of $\mathrm{CO}_{2}$ formed in the pulping process is biogenic, and the primary source of fossil-based $\mathrm{CO}_{2}$ is the lime kiln. Therefore, carbon capture offers pulp mills the 
possibility to act as site for negative $\mathrm{CO}_{2}$ emissions, if biogenic $\mathrm{CO}_{2}$ is permanently removed from the atmosphere by utilizing it as raw material for further bioproducts. The technical potential for carbon capture in pulp mills is notable, and it can be estimated to cover $3 \%$ of the global capture potential from bioenergy. Considering currently available technologies, the utilization possibilities in pulp mills are minor compared with the capture potential. Therefore, the possibilities for climate change mitigation using carbon capture in the chemical pulp industry center on carbon storage, and utilization possibilities require more research to become a notable option. The cost-effectiveness of BECCS/CCU is primarily dependent on the avoidance of cost of fossil $\mathrm{CO}_{2}$ emissions. In the future, the feasibility will depend both on technology development on $\mathrm{CO}_{2}$ utilization possibilities, and on political decision-making regarding emission taxes and possible incentives encouraging $\mathrm{CO}_{2}$-negative solutions.

Acknowledgments The authors gratefully acknowledge the support from the Academy of Finland.

Funding Open access funding provided by Lappeenranta University of Technology (LUT). This study was funded by the Academy of Finland (grant number 315019).

\section{Compliance with ethical standards}

Conflict of interest The authors declare that they have no conflict of interest.

Open Access This article is distributed under the terms of the Creative Commons Attribution 4.0 International License (http://creativecommons.org/licenses/by/4.0/), which permits unrestricted use, distribution, and reproduction in any medium, provided you give appropriate credit to the original author(s) and the source, provide a link to the Creative Commons license, and indicate if changes were made.

Publisher's Note Springer Nature remains neutral with regard to jurisdictional claims in published maps and institutional affiliations.

\section{References}

Abanades JC, Rubin ES, Mazzotti M, Herzog HJ (2017) On the climate change mitigation potential of $\mathrm{CO}_{2}$ conversion to fuels. Energy Environ Sci 10:2491-2499. https://doi.org/10.1039/C7EE02819A

Aro T, Fatehi P (2017) Tall oil production from black liquor: challenges and opportunities. Sep Purif Technol 175:469-480. https://doi.org/10.1016/j.seppur.2016.10.027

de Coninck H, Revi A, Babiker M, Bertoldi P, Buckeridge M, Cartwright A, Dong W, Ford J, Fuss S, Hourcade JC, Ley D, Mechler R, Newman P, Revokatova A, Schultz S, Steg L, Sugiyama T (2018) Strengthening and implementing the global response. In: Masson-Delmotte V, Zhai P, Pörtner HO, Roberts D, Skea J, Shukla PR, Pirani A, Moufouma-Okia W, Péan C, Pidcock R, Connors S, Matthews JBR, Chen Y, Zhou X, Gomis MI, Lonnoy E, Maycock T, Tignor M, Waterfield T (eds) Global warming of $1.5^{\circ} \mathrm{C}$. An IPCC Special Report on the impacts of global warming of $1.5^{\circ} \mathrm{C}$ above pre-industrial levels and related global greenhouse gas emission pathways, in the context of strengthening the global response to the threat of climate change, sustainable development, and efforts to eradicate poverty. In Press

Food and Agriculture Organization of the United Nations (FAO) (2017) Forestry production and trade statistics. http://www.fao.org/faostat/en/\#data/FO. Accessed 26 February 2018

Fridahl M, Lehtveer M (2018) Bioenergy with carbon capture and storage (BECCS): global potential, investment preferences, and deployment barriers. Energy Res Soc Sci 42:155-165. https://doi.org/10.1016/j. erss.2018.03.019 
Gullichsen J, Lindeberg H (2000) Byproducts of chemical pulping. In: Gullichsen J, Fogelholm C-J (eds) Chemical pulping, vol 6B. Finnish Paper Engineers' Association, Helsinki, pp 374-389

Hamaguchi M, Vakkilainen E, Ryder P (2011) The impact of lignin removal on the dimensioning of eucalyptus pulp mills. Appita J 64(5):433-439

Hamaguchi M, Kautto J, Vakkilainen E (2013) Effects of hemicellulose extraction on the kraft pulp mill operation and energy use: review and case study with lignin removal. Chem Eng Res Des 91(7):1284 1291. https://doi.org/10.1016/j.cherd.2013.02.006

Hirsch G, Kersten A, Putz H-J, Bobek B, Hamm U, Schabel S (2013) $\mathrm{CaCO}_{3}$ in the paper industry - blessing or curse? Proceedings of Tappi PEERS conference

Intergovernmental Panel on Climate Change (IPCC) (2018) Summary for policymakers. In: Masson-Delmotte V, Zhai P, Pörtner HO, Roberts D, Skea J, Shukla PR, Pirani A, Moufouma-Okia W, Péan C, Pidcock R, Connors S, Matthews JBR, Chen Y, Zhou X, Gomis MI, Lonnoy E, Maycock T, Tignor M, Waterfield T (eds) Global warming of $1.5^{\circ} \mathrm{C}$. An IPCC special report on the impacts of global warming of $1.5^{\circ} \mathrm{C}$ above pre-industrial levels and related global greenhouse gas emission pathways, in the context of strengthening the global response to the threat of climate change, sustainable development, and efforts to eradicate poverty. World Meteorological Organization, Geneva, Switzerland. pp 1-32

International Energy Agency (IEA) (2014) Energy technology perspectives 2014. OECD/IEA

International Energy Agency (IEA) (2018) Statistics. https://www.iea.org/statistics/. Accessed 11 October 2018

International Energy Agency Greenhouse Gas R\&D Programme (IEAGHG) (2016) Techno-economic evaluation of retrofitting ccs in a market pulp mill and an integrated pulp and board mill. IEA Environmental Projects Ltd, Cheltenham

Karjunen H, Tynjälä T, Hyppänen T (2017) A method for assessing infrastructure for $\mathrm{CO}_{2}$ utilization: a case study of Finland. Appl Energy 205:33-34. https://doi.org/10.1016/j.apenergy.2017.07.111

Kuparinen K, Vakkilainen EK (2017) Green pulp mill: renewable alternatives to fossil fuels in lime kiln operations. BioResources 12:4031-4048. https://doi.org/10.15376/biores.12.2.4031-4048

Kuparinen K, Vakkilainen EK, Hamaguchi M (2017) Analysis on fossil fuel-free operation in a northern pulp and paper mill. Proceeding of International Chemical Recovery Conference

Leeson D, Mac Dowell N, Shah N, Petit C, Fennell PS (2017) A techno-economic analysis and systematic review of carbon capture and storage (CCS) applied to the iron and steel, cement, oil refining and pulp and paper industries, as well as other high purity sources. Int J Greenhouse Gas Control 61:71-84. https://doi. org/10.1016/j.ijggc.2017.03.020

Martínez I, Grasa G, Parkkinen J, Tynjälä T, Hyppänen T, Murillo R, Romano MC (2016) Review and research needs of Ca-looping systems modelling for post-combustion $\mathrm{CO}_{2}$ capture applications. Int J Greenhouse Gas Control 50:271-304. https://doi.org/10.1016/j.ijggc.2016.04.002

Metsä Group (2016) Metsä Group's bioproduct concept is progressing. Press Release 17 February 2016

Nanri Y, Konno H, Goto H, Takahashi K (2008) A new process to produce high-quality PCC by the causticizing process in a kraft pulp mill. TAPPI J 7(5):19-24

Onarheim K, Garðarsdòttir SÒ, Mathisen A, Nord LO, Berstad D (eds) (2015) Industrial implementation of carbon capture in Nordic industry sectors. Nordic CCS Competence Centre NORDICCS

Onarheim K, Santos S, Kangas P, Hankalin V (2017) Performance and costs of ccs in the pulp and paper industry part 1: performance of amine-based post-combustion $\mathrm{CO}_{2}$ capture. Int J Greenhouse Gas Control 59:58-73. https://doi.org/10.1016/j.ijggc.2017.02.008

Romano MC, Spinelli M, Campanari S, Consonni S, Cinti G, Marchi M, Borgarello E (2013) The calcium looping process for low $\mathrm{CO}_{2}$ emission cement and power. Energy Procedia 37:7091-7099. https://oi. org/10.1016/j.egypro.2013.06.645

Shackford LD (2003) A comparison of pulping and bleaching of kraft softwood and eucalyptus pulps. 36th International Pulp and Paper Congress and Exhibition

Stanger R, Wall T, Spörl R, Paneru M, Grathwohl S, Weidmann M, Scheffknecht G, McDonald D, Myöhänen K, Ritvanen J, Rahiala S, Hyppänen T, Mletzko J, Kather A, Santos S (2015) Oxyfuel combustion for $\mathrm{CO}_{2}$ capture in power plants. Int J Greenhouse Gas Control 40:55-125. https://doi.org/10.1016/j. ijggc.2015.06.010

Sun R, Li Y, Liu C, Xie X, Lu C (2013) Utilization of lime mud from paper mill as $\mathrm{CO}_{2}$ sorbent in calcium looping process. Chem Eng J 221:124-132. https://doi.org/10.1016/j.cej.2013.01.068

Teir S, Eloneva S, Zevenhoven R (2005) Production of precipitated calcium carbonate from calcium silicates and carbon dioxide. Energy Convers Manag 46(18):2954-2979. https://doi.org/10.1016/j. enconman.2005.02.009

Tomani P (2013) Update on LignoBoost lignin and applications. Svenska Pappers- och Cellulosaingeniörsföreningen (SPCI), Stockholm

Tran H, Vakkilainen EK (2007) Advances in the kraft chemical recovery process. International Colloquium on Eucalyptus Pulp 
Tynjälä T, Vakkilainen E, Hyppänen T (2014) Renewable $\mathrm{CO}_{2}$ production for power to gas concept by calcium looping process. 1st International Conference on Renewable Energy Gas Technology (REGATEC)

Vakkilainen E, Kivistö A (2008) Fossil fuel replacement in the pulp mills. Lappeenranta University of Technology, Lappeenranta

Vakkilainen E, Kivistö A (2014) Forest industry energy consumption - trends and effects of modern mills. Lappeenranta University of Technology, Lappeenranta

Vakkilainen EK, Kuparinen K, Heinimö J (2013) Large industrial users of energy biomass. IEA Bioenergy Task 40 